\title{
Penerapan Grafik Kendali Mixed Multivariate EWMA- CUSUM pada Pengendalian Kualitas Air Produksi PDAM Surya Sembada Surabaya
}

\author{
Nisfi Hemas Diga Asmara dan Wibawati \\ Statistika, Fakultas Sains dan Analitika Data (FSAD), Institut Teknologi Sepuluh Nopember (ITS) \\ Jl. Arief Rahman Hakim, Surabaya 60111 Indonesia \\ e-mail:wibawati@statistika.its.ac.id
}

\begin{abstract}
Abstrak - PDAM Surya Sembada Surabaya merupakan perusahaan milik pemerintah Kota Surabaya yang bergerak dalam bidang pengolahan air minum. Visi dari perusahaan PDAM Surya Sembada adalah menjadi perusahaan air minum modern. Oleh karena itu, kualitas air produksi PDAM Surya Sembada Surabaya harus selalu diperhatikan. Selain itu kualitas kebersihan air bersih dapat dilihat dari parameter fisika, kimia, mikrobiologi, serta radioaktivitas yang terdapat pada air, hal tersebut diatur pada Peraturan Menteri Kesehatan RI No. 416 tahun 1990. Jika terdapat perubahan karakteristik pada air maka kualitas air juga akan menurun. Oleh karena itu akan dilakukan penelitian mengenai pengendalian kualitas pada air produksi PDAM Surya Sembada Surabaya. Penelitian ini akan dilakukan menggunakan grafik kendali multivariat penggabungan dari MEWMA-MCUSUM yang disebut dengan grafik kendali MEC. Grafik kendali MEC terbagi menjadi dua yaitu MEC1 dan MEC2. Variabel yang akan digunakan adalah turbidity, sisa Chlor, dan Zat Organik KMnO4. Setelah dilakukan analisis pengendalian kualitas menggunakan MEC1 dan MEC2 maka akan dibandingkan grafik kendali yang memberikan hasil terbaik pada data turbidity, sisa Chlor, dan zat organik. Pada hasil penelitian yang telah dilakukan menggunakan grafik kendali MEC1 dan MEC2 didapatkan hasil bahwa proses produksi air produksi tidak terkendali secara statistik. Grafik kendali MEC1 yang diterapkan pada data penelitian ini lebih sensitif dari grafik MEC2 karena menghasilkan lebih banyak pengamatan yang out of control. Setelah dilakukan identifikasi, variabel zat organik adalah variabel yang berpengaruh paling besar terhadap terjadinya out of control. Jika dilihat dari kapabilitas prosesnya, proses produksi air produksi di PDAM Surya Sembada Surabaya IPAM Ngagel I tidak kapabel. Penelitian ini diharapkan dapat memberikan manfaat kepada perusahaan PDAM Surya Sembada Surabaya sebagai evaluasi proses produksi air.
\end{abstract}

Kata Kunci - Grafik Kendali, Pengendalian Kualitas, PDAM Surya Sembada Surabaya, MEC.

\section{PENDAHULUAN}

A ir merupakan bahan alam yang diperlukan untuk memenuhi kebutuhan dalam kehidupan manusia, hewan dan tanaman dan juga merupakan sumber energi serta berbagai keperluan lainnya. Oleh karena itu persediaan air bersih sangat diperlukan [1]. Indikator air telah tercemar adalah terdapat perubahan yang dapat diamati seperti perubahan warna air, suhu, pH, bau, dan rasa [2]. Kebutuhan akan air bersih akan semakin meningkat seiring dengan bertambahnya jumlah penduduk di suatu wilayah sehingga diperlukan instalasi untuk mengolah air bersih yang memenuhi standar. Kota Surabaya pada tahun 2019 memiliki jumlah penduduk sebanyak 3.095.026 jiwa penduduk sehingga diperlukan air bersih yang cukup untuk memenuhi kebutuhan masyarakat Kota Surabaya.

PDAM Surya Sembada Surabaya merupakan Badan Usaha Milik Daerah (BUMD) Pemerintah Kota Surabaya yang bergerak dalam bidang pengolahan air minum. Visi dari PDAM
Surya Sembada Surabaya adalah "Menjadi Perusahaan Air Minum Modern" dengan misi yang dilakukan antara lain yaitu memastikan pengelolaan keuangan yang transparan untuk kesejahteraan masyarakat, membangun masyarakat yang bijak dalam penggunaan air, menyediakan air minum yang efisien dan berkelanjutan, serta membangun lingkungan kerja yang memprioritaskan integritas dan prestasi [3]. Pada tahun 2016 PDAM Surya Sembada Surabaya memiliki pelanggan yang menggunakan pelayanan PDAM Surya Sembada Surabaya sebanyak 547.819 meliputi perumahan, pemerintah, perdagangan, industri, dan pelabuhan.

Kualitas air minum harus sangat diperhatikan agar selalu aman dan sehat saat dikonsumsi oleh masyarakat. Kualitas air minum dapat dikendalikan dengan menggunakan analisis statistika yakni menggunakan pengendalian kualitas statistik atau statistical process control (SPC). Pengendalian kualitas statistik merupakan alat statistika yang mampu mengontrol produk pada proses produksi, salah satunya dapat menggunakan grafik kendali. Grafik kendali merupakan alat ukur statistika secara grafis yang dapat memonitor sebuah proses produksi sudah berada dalam batas kendali atau tidak [4]. Oleh karena itu, pada penelitian ini akan dilakukan monitoring kualitas air minum produksi PDAM Surya Sembada Surabaya di IPAM Ngagel I. Pengendalian kualitas air produksi di PDAM Surya Sembada Surabaya melibatkan karakteristik penentu kualitas air antara lain adalah turbidity (kekeruhan air), zat organik $\mathrm{KMnO}_{4}$, dan sisa Chlor.

Berdasarkan uraian dan penelitian sebelumnya maka pada penelitian ini dilakukan monitoring kualitas air minum produksi PDAM Surya Sembada Surabaya menggunakan grafik kendali $M E C$ dan diharapkan dapat memberi manfaat kepada PDAM Surya Sembada Surabaya agar bisa memberikan treatment pada produksi air minum sehingga akan mengurangi kerugian yang mungkin terjadi. Variabel yang digunakan pada penelitian ini adalah Turbidity atau kekeruhan air. Variabel Turbidity diteliti karena terdapat perubahan warna pada air maka hal tersebut bisa terlihat jelas sehingga bisa diteliti lebih lanjut untuk mengetahui telah terjadi pergeseran proses produksi atau tidak. Selain itu juga digunakan variabel sisa Chlor dan zat organik merupakan parameter utama dalam penentuan kualitas air di PDAM Surya Sembada Surabaya. Selain itu juga dilakukan analisis kapabilitas proses untuk mengetahui proses produksi air produksi sudah kapabel atau tidak.

\section{TINJAUAN PUSTAKA}

\section{A. Uji Distribusi Normal Multivariat}

Sebelum melakukan pengendalian kualitas diperlukan pengujian distribusi normal pada data yang digunakan untuk menentukan data pengamatan mengikuti persebaran distribusi 
normal atau tidak. Suatu pengamatan $x_{1}, x_{2}, \ldots, x_{p}$ dikatakan memiliki distribusi normal multivariat ketika memiliki fungsi densitas seperti pada persamaan (1) [5].

$$
f(x)=\frac{1}{(2 \pi)^{p / 2}|\Sigma|^{1 / 2}} e^{-\frac{1}{2}(\mathbf{X}-\boldsymbol{\mu})^{T} \boldsymbol{\Sigma}^{-1}(\mathbf{X}-\boldsymbol{\mu})},
$$

dengan $\mathbf{X}$ merupakan data pengamatan dan $\boldsymbol{\Sigma}$ adalah matriks kovarians. Uji distribusi normal yang digunakan adalah pengujian Shapiro- Wilk dengan hipotesis dan statistik uji pada persamaan (2).

Hipotesis :

$\mathrm{H}_{0}$ : data berdistribusi normal multivariat.

$\mathrm{H}_{1}$ : data tidak berdistribusi normal multivariat.

Statistik uji :

$$
W^{*}=\frac{1}{p} \sum_{i=1}^{p} W_{z_{i}}
$$

dengan

$$
W_{z_{i}}=\frac{\left[\sum_{i=1}^{n} a_{i} x_{(i)}\right]^{2}}{\sum_{i=1}^{n}\left(x_{i}-\bar{x}\right)^{2}} .
$$

$W^{*}$ merupakan statistik uji normal multivariat untuk uji Shapiro Wilk, sedangkan $W_{z i}$ merupakan statistik uji dari Shapiro Wilk pada observasi ke-i yang telah ditransformasi. Jika nilai $W^{*}>C_{\alpha ; n ; p}$ maka keputusan yang diambil adalah gagal tolak $H_{0}$. Selain itu pengujian normal multivariat juga bisa dideteksi menggunakan nilai $p$-value dimana jika $p$-value $>\alpha(0,05)$ maka keputusan yang diambil adalah gagal tolak $\mathrm{H}_{0}$ yang artinya data mengikuti persebaran distribusi normal multivariat.

\section{B. Uji Bartlett}

Uji Bartlett dilakukan untuk mengetahui apakah terdapat hubungan varians antar variabel multivariat. Jika $X_{l}, X_{2}, \ldots, X_{k}$ memiliki sifat saling bebas atau tidak saling berhubungan, maka matriks korelasi antar variabel sama dengan matriks identitas. Uji Bartlett digunakan ketika data mengikuti persebaran distribusi normal. Bartlett sphericity didefinisikan pada hipotesis dan statistik uji pada persamaan (4). Pada penelitian ini jumlah variabel yang digunakan adalah 3 sehingga uji Bartlett menggunakan Chi-square dengan hipotesis sebagai berikut.

$\mathrm{H}_{0}: \mathbf{R}=\mathbf{I}$ (tidak terdapat korelasi antar variabel).

$\mathrm{H}_{1}: \mathbf{R} \neq \mathbf{I}$ (terdapat korelasi antar variabel).

Statistik uji :

$$
\chi_{\text {hitung }}^{2}=-\left[n-1-\frac{2 p+5}{6}\right] \ln |\mathbf{R}|,
$$

dimana $n$ merupakan jumlah observasi, $p$ adalah jumlah karakteristik kualitas, dan $\mathbf{R}$ adalah matriks korelasi dari setiap variabel. Jika $\chi_{\text {hitung }}^{2}>\chi_{\left(\alpha ; \frac{1}{2} p(p-1)\right.}^{2}$ maka keputusan yang diambil adalah tolak $\mathrm{H}_{0}$ dan diartikan bahwa terdapat korelasi antar variabel [6].

\section{Pengendalian Kualitas}

Pengendalian kualitas atau statistical process control $(S P C)$ merupakan kegiatan penyelesaian sebuah masalah untuk mencapai proses yang stabil serta mampu mengurangi variabilitas dalam proses. Selain itu, pengendalian kualitas juga digunakan untuk menggambarkan variabilitas yang dapat dikendalikan maupun tidak dapat dikendalikan. Terdapat beberapa alat untuk mengendalikan kualitas salah satunya yaitu grafik kendali [4].

\section{Grafik Kendali Mixed Multivariate Exponentially Weighted Moving Average - Cumulative Sum (MEC)}

Grafik kendali $M E C$ merupakan gabungan dari grafik kendali $M E W M A$ dan $M C U S U M$ dan dibagi menjadi dua yaitu $M E C 1$ dan $M E C 2$. Grafik kendali $M E W M A$ ditulis pada persamaan (5), matriks kovarians pada persamaan (6), serta statistik pada persamaan (7)

$$
\begin{gathered}
\mathbf{Z}_{\mathrm{i}}=\lambda \mathbf{X}_{\mathrm{i}}+(1-\lambda) \mathbf{Z}_{\mathrm{i}-1}, \\
\boldsymbol{\Sigma}_{Z_{i}}=\frac{\lambda}{2-\lambda} \boldsymbol{\Sigma},
\end{gathered}
$$

dan

$$
T_{i}^{2}=\mathbf{Z}_{i}^{T} \boldsymbol{\Sigma}_{Z}^{-1} \mathbf{Z}_{i}
$$

Statistik $T_{i}^{2}$ merupakan titik yang diplot pada grafik kendali. Jika $T_{i}^{2}$ melebihi upper control limit (UCL) maka proses dikatakan tidak terkendali secara statistik. Sementara grafik $M C U$ SUM memiliki statistik pada persamaan (8). MCUSUM dikembangkan menjadi grafik $M C 1$ dengan dasar kuadrat dari vektor mean pada persamaan (9) dan statistik pada persamaan (10).

$$
\begin{gathered}
C_{i}=\left\{\left(\mathbf{S}_{i-1}+\mathbf{X}_{i}\right)^{T} \boldsymbol{\Sigma}^{-1}\left(\mathbf{S}_{i-1}+\mathbf{X}_{i}\right)\right\}^{\frac{1}{2}}, \\
\mathbf{S}_{i}=\sum_{j=i-n_{i}+1}^{i}\left(\overline{\mathbf{X}}_{i}-\boldsymbol{\mu}_{0}\right),
\end{gathered}
$$

dan

$$
V_{i}=\max \left\{0,\left(\mathbf{S}_{i}^{T} \boldsymbol{\Sigma}^{-1} \mathbf{S}_{i}\right)^{\frac{1}{2}}-k n_{i}\right\} .
$$

Selanjutnya adalah grafik kendali $M E C l$ yang merupakan bentuk transformasi grafik kendali MEWMA dengan MCUSUM dengan persamaan (11). Nilai $\mathbf{k}^{*}$ dapat dihitung menggunakan persamaan (12) dan selanjutnya dapat diperoleh MEC $_{i}$ pada persamaan (13).

$$
\begin{aligned}
& \mathbf{M E C}_{i}=\max \left(0, \mathbf{M E C}_{i-1}+\left(\mathbf{Z}_{i}-\boldsymbol{\mu}_{0}\right)-\mathbf{k}^{*}\right), \\
& \mathbf{k}^{*}=k \frac{\mathbf{M E C}_{i-1}+\mathbf{Z}_{i}-\boldsymbol{\mu}_{0}}{\left[\left(\mathbf{M E C}_{i-1}+\mathbf{Z}_{i}-\boldsymbol{\mu}_{0}\right)^{T} \boldsymbol{\Sigma}_{Z_{i}}{ }^{-1}\left(\mathbf{M E C}_{i-1}+\mathbf{Z}_{i}-\boldsymbol{\mu}_{0}\right)\right]^{\frac{1}{2}}} ; \\
& k \in R^{+}, k>0,
\end{aligned}
$$

dan

$$
\mathbf{M E C}_{i}=\mathbf{M E C}_{i-1}+\left(\mathbf{Z}_{i}-\boldsymbol{\mu}_{0}\right)-\mathbf{k}^{*} .
$$

Setelah mendapatkan $\mathbf{M E C}_{\mathrm{i}}$ maka selanjutnya adalah mencari statistik $M E C 1_{\mathrm{i}}$ dengan persamaan (14). Pengamatan dikatakan tidak terkendali secara statistik apabila terdapat pengamatan yang berada di luar batas kendali dengan indikasi nilai $M E C 1_{\mathrm{i}}>U C L$.

$$
\operatorname{MECl}_{i}=\mathbf{M E C}_{i}^{T} \boldsymbol{\Sigma}_{Z}^{-1} \mathbf{M E C}_{i} .
$$

Grafik kendali kedua adalah grafik kendali $M E C 2$ merupakan gabungan dari grafik kendali $M E W M A$ dengan MC1. Selanjutnya vektor cumulative sums didefinisikan pada persamaan (15) yang akan dimasukkan ke dalam statistik $M E C 2_{\text {i }}$ pada persamaan (16).

$$
\mathbf{S}_{i}=\sum_{j=i-n_{i}+1}^{i}\left(\mathbf{Z}_{i}-\boldsymbol{\mu}_{0}\right),
$$


dan

$$
M E C 2_{i}=\max \left\{0,\left(\mathbf{S}_{i}^{T} \boldsymbol{\Sigma}_{Z_{i}}{ }^{-1} \mathbf{S}_{i}\right)^{\frac{1}{2}}-k_{1} n_{i}\right\} .
$$

Pengamatan dikatan tidak terkendali secara statistik jka terdapat nilai pengamatan $M E C 2_{\mathrm{i}}>U C L$.

\section{E. Kapabilitas Proses}

Analisis kapabilitas dilakukan untuk menaksir kemampuan suatu proses. Diperlukan indeks kapabilitas yang dapat digunakan untuk mengetahui kemampuan suatu proses. Suatu proses produksi dikatakan mampu atau kapabel apabila memiliki indeks kapabilitas lebih dari 1. Indeks kapabilitas yang disarankan untuk proses dalam keadaan in control adalah $C_{p}$ dan $C_{p k}$, sedangkan untuk proses yang tidak dalam keadaan in control, digunakan indeks performance process $P_{p}$ dan $P_{p k}$ [7]. Pada perhitungan $C_{p}$ diperlukan nilai upper control limit $(U C L)$ dan lower control limit (LCL) dan juga standar deviasi sampel $(\sigma)$ yang didefinisikan pada persamaan (17). Namun, dalam pengaplikasiannya standar deviasi proses hampir tidak diketahui dan harus diestimasi sehingga diperoleh persamaan (18).

$$
\begin{gathered}
C_{p}=\frac{U C L-L C L}{6 \sigma} . \\
\widehat{C}_{p}=\frac{U C L-L C L}{6 \widehat{\sigma}} .
\end{gathered}
$$

$C_{p k}$ merupakan perbaikan dari $C_{p}$ yang menunjukkan presisi dan akurasi proses. $C_{p k}$ dapat diperoleh menggunakan persamaan (19).

$$
C_{p k}=\min \left(\frac{U C L-\mu}{3 \sigma}, \frac{\mu-L C L}{3 \sigma}\right) .
$$

Terdapat juga indeks $P_{p}$ yang digunakan pada saat proses tidak terkendali secara statistik. $P_{p}$ dapat dinyatakan pada rumus pada persamaan (20) dan $P_{p k}$ pada persamaan (21).

$$
\begin{gathered}
\widehat{P}_{p}=\frac{U C L-L C L}{6 s} . \\
P_{p k}=\min \left(\frac{U C L-\mu}{3 s}, \frac{\mu-L C L}{3 s}\right) .
\end{gathered}
$$

Pada data mutivariat indeks kapabilitas yang digunakan adalah $M P_{p}$ dan $M P_{p k}$ yang dapat dihitung dengan rumus pada persamaan (22) dan (23).

$$
\begin{aligned}
& M P_{p}=\sum_{k=1}^{p} W_{k} P_{p}\left(X_{k}\right) . \\
& M P_{p k}=\sum_{k=1}^{p} W_{k} P_{p k}\left(X_{k}\right) .
\end{aligned}
$$

dengan $W_{k}$ menunjukkan bobot dari karakteristik kualitas ke$j$, dengan ketentuan $\sum_{j=1}^{p} W_{j}=1[8]$.

\section{F. PDAM Surya Sembada Surabaya}

PDAM Surya Sembada Surabaya merupakan perusahaan milik Pemerintah Kota Surabaya yang bergerak dalam bidang pengolahan air baku menjadi air layak dikonsumsi. PDAM Surya Sembada Surabaya memiliki 6 instalasi pengolahan air minum (IPAM) antara lain adalah IPAM Ngagel I, IPAM Ngagel II, IPAM Ngagel III, IPAM Karangpilang I, IPAM Karangpilang II, dan IPAM Karangpilang III. Proses pengolahan air di PDAM Surya Sembada Surabaya diawali dari intake, aerasi, prasedimentasi, koaulasi-flokulasi, filtrasi, desinfektasn, dan reservoir sehingga air siap didistribusikan ke pelanggan. Pengolahan air dari proses aerasi hingga desinfektasn membutuhkan waktu selama 6 jam untuk 1700 liter/detik [3].

\section{METODOLOGI PENELITIAN}

\section{A. Sumber Data}

Penelitian ini menggunakan data sekunder yang didapatkan dari PDAM Surya Sembada Surabaya IPAM Ngagel I. Data yang digunakan dibagi menjadi musim kemarau (1 April 2019-30 November 2019) dan musim penghujan (1 Desember 2019 - 31 Maret 2020).

\section{B. Variabel Penelitian}

Variabel penelitian yang digunakan pada penelitian ini adalah karakteristik kualitas air yaitu turbidity (kekeruhan), sisa Chlor, dan zat organik $\mathrm{KMnO}_{4}$. Spesifikasi pada masingmasing variabel terdapat pada Tabel 1 .

Tabel 1. Variabel Penelitian

\begin{tabular}{cccc}
\hline \hline Variabel & Keterangan & Satuan & Spesifikasi \\
\hline $\mathrm{X}_{1}$ & Turbidity & $\mathrm{NTU}$ & $<5 \mathrm{NTU}$ \\
$\mathrm{X}_{2}$ & Zat Organik & $\mathrm{mg} / \mathrm{l}$ & $<10 \mathrm{mg} / \mathrm{l}$ \\
$\mathrm{X}_{3}$ & Sisa Chlor & $\mathrm{mg} / \mathrm{l}$ & $<1 \mathrm{mg} / \mathrm{l}$ \\
\hline \hline
\end{tabular}

\section{Langkah Analisis}

Langkah-langkah analisis pada penelitian ini adalah sebagai berikut.

1. Merumuskan masalah dan tujuan penelitian.

2. Melakukan analisis statistika deskriptif pada masingmasing variabel penentu kualitas air.

3. Melakukan pengujian asumsi normal multivariat pada variabel turbidity, zat organik $\mathrm{KMnO}_{4}$, dan sisa Chlor.

4. Melakukan pengujian dependensi antar variabel menggunakan uji Bartlett pada variabel turbidity, zat organik $\mathrm{KMnO}_{4}$, dan sisa Chlor pada masing-masing data kualitas air di musim kemarau dan penghujan.

5. Melakukan pengontrolan mean proses menggunakan grafik kendali $M E C 1$ dan $M E C 2$ pada proses produksi air pada masing-masing musim kemarau dan musim penghujan.

6. Membandingkan grafik kendali $M E C 1$ dan $M E C 2$.

7. Mengidentifikasi penyebab out of control dengan kombinasi dua variabel karakteristik kualitas di musim kemarau dan penghujan.

8. Menghitung kapabilitas proses secara univariat dan multivariat.

9. Menginterpretasi hasil analisis.

10. Membuat kesimpulan dan saran.

\section{HASIL DAN PEMBAHASAN}

\section{A. Karakteristik Variabel Kualitas Air Produksi}

Sebelum proses pendistribusian dilakukan pengontrolan kualitas air produksi dan akan diperoleh deskripsi karakteristik utama kulitas air produksi yaitu turbidity, zat organik $\mathrm{KMnO}_{4}$, serta sisa Chlor untuk mengetahui gambaran umum tentang variabel penentu baik buruknya kualitas air produksi seperti pada Tabel 2. 
Tabel 2. Deskripsi Karakteristik Kualitas Air Produksi IPAM Ngagel I

\begin{tabular}{llcccc}
\hline \hline \multicolumn{1}{c}{ Variabel } & Musim & Mean & Varians & Min & Maks \\
\hline $\begin{array}{l}\text { Turbidity } \\
\left(\mathrm{X}_{1}\right)\end{array}$ & Kemarau & 0,87 & 0,06 & 0,32 & 2,80 \\
\hline Zat Organik & Kemarau & 7,43 & 4,01 & 3,18 & 14,70 \\
$\mathrm{KMnO}_{4}\left(\mathrm{X}_{2}\right)$ & Penghujan & 8,22 & 5,69 & 2,74 & 13,81 \\
\hline Sisa Chlor & Kemarau & 0,53 & 0,11 & 0,00 & 1,86 \\
$\left(\mathrm{X}_{3}\right)$ & Penghujan & 0,78 & 0,08 & 0,14 & 1,48 \\
\hline \hline
\end{tabular}

Berdasarkan Tabel 2 terlihat bahwa rata-rata variabel turbidity pada musim kemarau lebih besar dari turbidity di musim penghujan, sedangkan pada zat organik $\mathrm{KMnO}_{4}$ dan sisa Chlor memiliki rata-rata lebih besar di musim penghujan serta sudah berada di dalam batas spesifikasi yang telah ditentukan. Jika dilihat dari nilai maksimum data kualitas air pada variabel zat organik $\mathrm{KMnO}_{4}$ dan sisa Chlor di musim kemarau maupun di musim penghujan berada di luar batas spesifikasi yang sudah ditentukan perusahaan berdasarkan peraturan Menteri Kesehatan Republik Indonesia. Hal tersebut dapat dapat dipengaruhi oleh banyaknya zat pencemar sehingga penambahan zat untuk mengurangi pencemar pada air.

\section{B. Pemeriksaan Asumsi Normal dan Dependensi}

Tiga karakteristik penentu kualitas air produksi yang digunakan adalah turbidity, zat organik $\mathrm{KMnO}_{4}$, dan sisa Chlor, sehingga perlu dilakukan pengujian asumsi normal multivariat dan memeriksa hubungan antar variabel saling dependen atau tidak. Pengujian asumsi normal multivariat dilakukan menggunakan uji Shapiro-Wilk.

Berdasarkan hasil pengujian normal multivariat menggunakan taraf signifikan $\alpha=5 \%$ menunjukkan hasil uji normalitas pada data kualitas air di musim kemarau dengan statistik uji $W^{*}=0,858$ dan $p$-value $=3,800 \times 10^{-14}$, sehingga dapat disimpulkan bahwa data kualitas air di musim kemarau tidak mengikuti persebaran distribusi normal multivariat karena memiliki nilai $p$-value < $\alpha$. Meskipun tidak berdistribusi normal multivariat analisis tetap dilanjutkan karena metode $M u$ ltivariate EWMA-CUSUM (MEC) bersifat robust terhadap distribusi yang tidak normal [9]. Sedangkan pada data kualitas air di musim penghujan memiliki statistik uji $W^{*}=0,982$ dan $p$ value $=0,114$, sehingga dapat disimpulkan bahwa data kualitas air produksi di musim penghujan mengikuti persebaran distribusi normal multivariat karena memiliki nilai $p$-value $>$ $\alpha$.

Selanjutnya pada pengujian asumsi dependensi menggunakan metode Bartlett dengan taraf signifikan $\alpha=5 \%$ menunjukkan hasil nilai chi-square sebesar 38,447 dengan derajat bebas adalah 3, dan nilai $p$-value sebesar 0,000. Karena nilai chisquare $>\chi_{0,05 ; 3}^{2}(7,815)$ dan nilai $p$-value $<\alpha$ yaitu sebesar $5 \%$, maka dapat disimpulkan bahwa ketiga variabel karakteristik kualitas air PDAM Surya Sembada Surabaya IPAM Ngagel I yaitu turbidity, zat organik $\mathrm{KMnO}_{4}$, dan sisa Chlor adalah dependen atau saling berhubungan satu sama lain.

\section{Monitoring Kualitas Air Menggunakan Grafik Kendali MEC}

Pengendalian kualitas secara statistik diperlukan untuk meningkatakan kualitas proses produksi air di PDAM Surya Sembada Surabaya IPAM Ngagel I. Pengendalian kualitas dilakukan pada tiga variabel penentu kualitas yaitu turbidity, zat organik $\mathrm{KMnO}_{4}$, dan juga sisa Chlor menggunakan grafik kendali Multivariate EWMA-CUSUM (MEC) dimana grafik kendali ini memiliki dua tipe yaitu $M E C 1$ dan $M E C 2$ untuk mendeteksi pergeseran proses. Data yang digunakan adalah data kualitas air produksi pada musim kemarau yaitu pada tanggal 1 April 2019 - 30 November 2019 serta pada musim penghujan yaitu pada tanggal 1 Desember 2019 - 31 Maret 2020. Pada penelitian ini digunakan nilai pembobot $\lambda$ sebesar $0,1,0,2$ dan 0,3 karena jika nilai pembobot semakin besar maka akan menghasilkan hasil yang bias.

\section{Monitoring Kualitas Air Menggunakan Grafik Kendali MECl}

Monitoring pertama yang dilakukan pada data kualitas air pada musim kemarau yaitu pada periode 1 April 2019 - 30 November 2019.

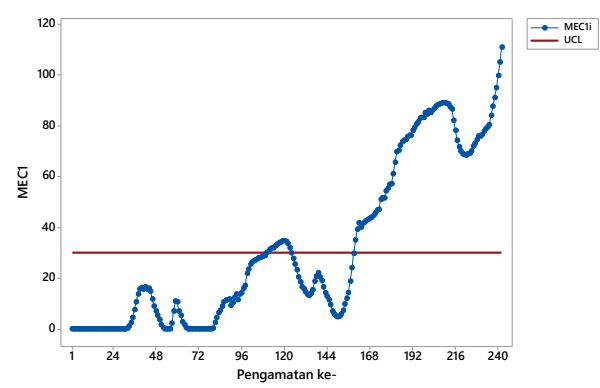

Gambar 1. Grafik Kendali MEC1 Musim Kemarau dengan $\lambda=0,1$

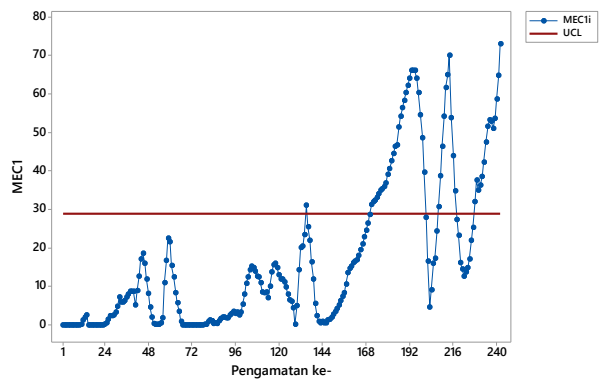

Gambar 2. Grafik Kendali MEC1 Musim Kemarau dengan $\lambda=0,2$

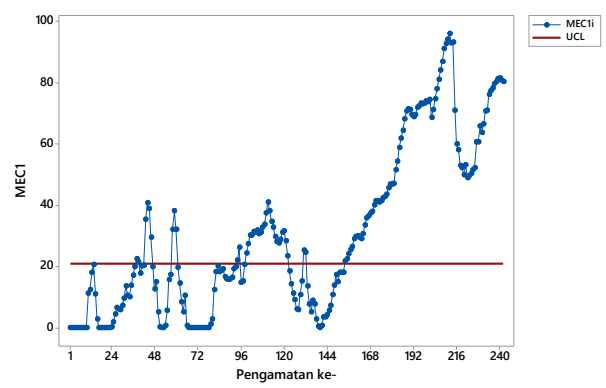

Gambar 3. Grafik Kendali MEC1 Musim Kemarau dengan $\lambda=0,3$

Pada Gambar 1 didapatkan informasi bahwa dengan menggunakan $\lambda=0,1$ dan $U C L=30,027$ terdapat sebanyak 96 pengamatan out of control atau yang di luar batas kendali. Selanjutnya pada Gambar 2 terdapat 56 pengamatan out of control, sedangkan pada monitoring seperti pada Gambar 3 didapatkan pengamatan out of control sebanyak 126 pengamatan. Oleh karena itu dari hasil monitoring dengan nilai pembobot 0,$1 ; 0,2$; dan 0,3 kualitas air produksi pada musim kemarau di IPAM Ngagel I tidak terkendali secara statistik. Nilai pembobot optimum pada musim kemarau adalah 0,3 karena memiliki jumlah pengamatan out of control terbanyak. Selanjutnya adalah monitoring kualitas air produksi dengan data pengamatan 
di musim penghujan. Monitoring yang sama dilakukan menggunakan nilai pembobot 0,$1 ; 0,2$; dan 0,3 .

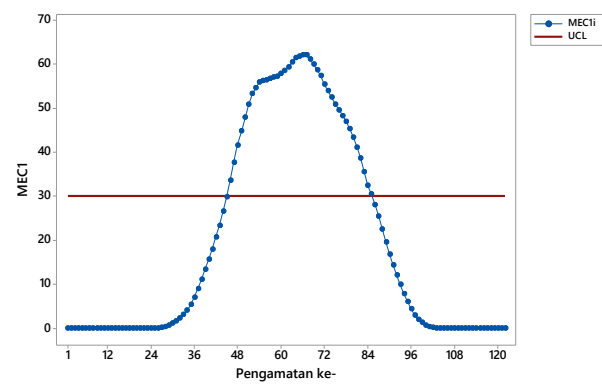

Gambar 4. Grafik Kendali MEC1 Musim Penghujan dengan $\lambda=0,1$

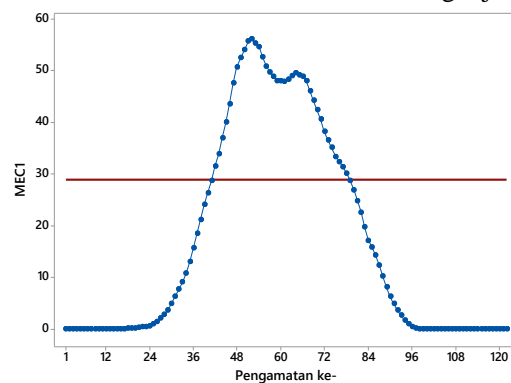

- MEcci

Gambar 5. Grafik Kendali MEC1 Musim Penghujan dengan $\lambda=0,2$

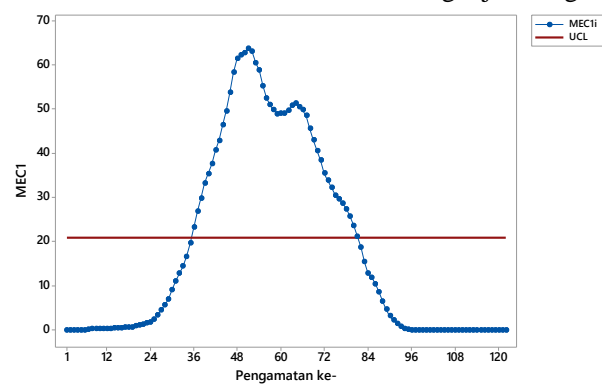

Gambar 6. Grafik Kendali MEC1 Musim Penghujan dengan $\lambda=0,3$

Pada Gambar 4 didapatkan informasi bahwa dengan dengan $\lambda=0,1$ dan $U C L=30,027$ terdapat 40 dari 122 kese luruhan pengamatan. Selanjutnya monitoring menggunakan $\lambda=0,2$ dan $U C L=28,940$ pada Gambar 5 diketahui bahwa terdapat 37 pengamatan out of control, sedangkan monitoring menggunakan $\lambda=0,3$ dan $U C L=20,890$ seperti pada Gambar 6 terdapat sebanyak 46 pengamatan out of control, sehingga dapat disimpulkan bahwa proses produksi air produksi IPAM Ngagel I di musim penghujan tidak terkendali secara statistik. Nilai pembobot optimum yang digunakan adalah 0,3 karena memiliki nilai pengamatan out of control terbanyak yaitu 46 pengamatan seperti pada Gambar 6. Proses selanjutnya adalah memonitor kualitas air produksi menggunakan grafik kendali MEC2.

\section{Monitoring Kualitas Air Menggunakan Grafik Kendali} MEC2

Monitoring kualitas air produksi dengan grafik kendali $M E C 2$ juga dilakukan menggunakan nilai pembobot 0,$1 ; 0,2$; dan 0,3 .

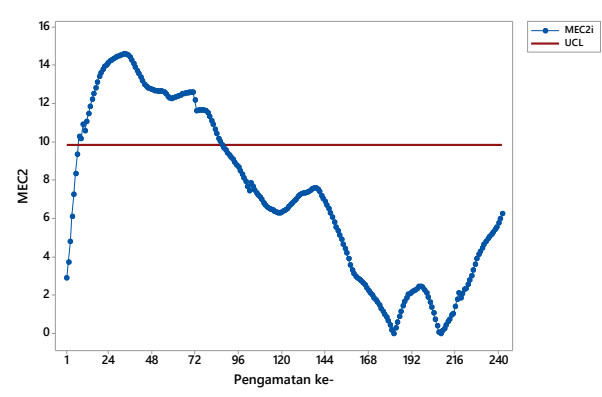

Gambar 7. Grafik Kendali $M E C 2$ Musim Kemarau dengan $\lambda=0,1$

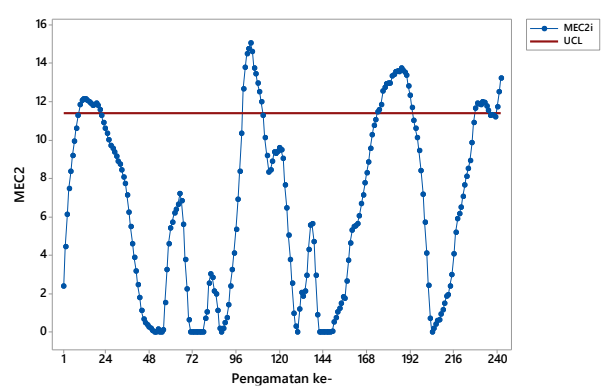

Gambar 8. Grafik Kendali MEC2 Musim Kemarau dengan $\lambda=0,2$

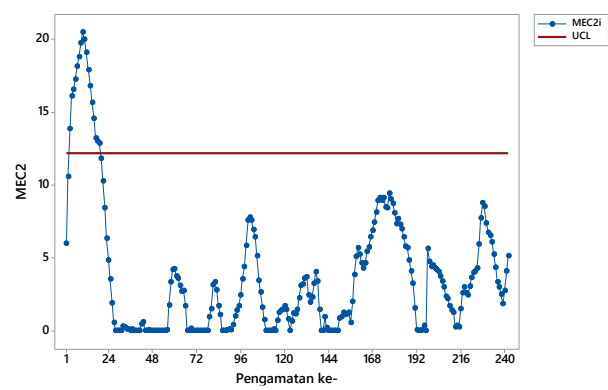

Gambar 9. Grafik Kendali MEC2 Musim Kemarau dengan $\lambda=0,3$

Pada monitoring kualitas air produksi menggunakan grafik kendali MEC2 dengan $\lambda=0,1$ dan $U C L$ 9,863 seperti pada Gambar 7 terdapat 79 dari 242 kelesuruhan pengamatan. Selanjutnya pada monitoring menggunakan $\lambda=0,2$ dan $U C L$ $=11,401$ pada Gambar 8 didapatkan informasi bahwa terdapat 54 pengamatan out of control, sedangkan pada monitoring dengan $\lambda=0,3$ dan $U C L=12,195$ seperti pada Gambar 9 terdapat 17 pengamatan out of control sehingga dapat disimpulkan bahwa proses produksi air produksi saat musim kemarau tidak terkendali secara statistik. Nilai pembobot optimum yang digunakan adalah 0,1 karena memiliki jumlah pengamatan out of control. Selanjutnya adalah proses monitoring menggunakan grafik kendali $M E C 2$ pada musim penghujan.

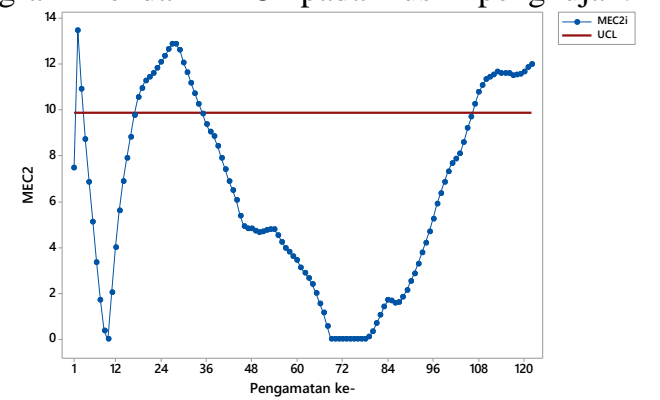

Gambar 10. Grafik Kendali MEC2 Musim Penghujan dengan $\lambda=0,1$ 


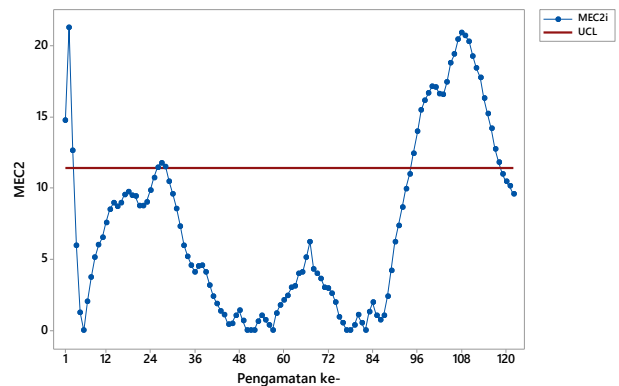

Gambar 11. Grafik Kendali $M E C 2$ Musim Penghujan dengan $\lambda=0,2$

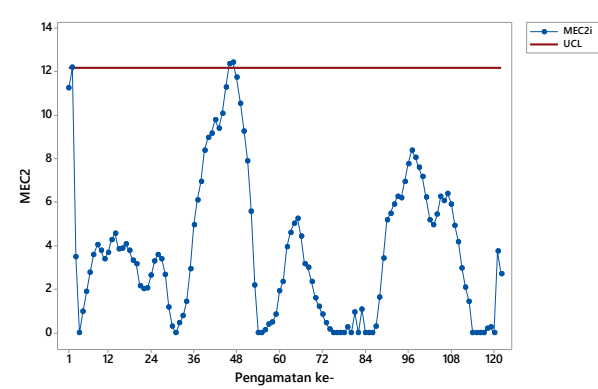

Gambar 12. Grafik Kendali $M E C 2$ Musim Penghujan dengan $\lambda=0,3$

Pada monitoring kualitas air produksi IPAM Ngagel I menggunakan grafik kendali MEC 2 dengan $\lambda=0,1$ dan $U C L$ $=9,863$ pada Gambar 10 diketahui bahwa terdapat 35 pengamatan out of control. Pada Gambar 11, monitoring dengan $\lambda=$ 0,2 dan $U C L=11,401$ didapatkan pengamatan out of control sebanyak 30 pengamatan out of control, sedangkan pada monitoring dengan $\lambda=0,3$ dan $U C L=11,401$ pada Gambar 12 hanya terdapat 2 pengamatan out of control, sehingga disimpulkan bahwa proses produksi air produksi di musim penghujan menggunakan grafik kendali $M E C 2$ tidak terkendali secara statistik. Nilai pembobot optimum yang digunakan adalah 0,1 karena memiliki jumlah out of control terbanyak.

\section{Perbandingan $M E C 1$ dan $M E C 2$}

Setelah melakukan proses monitoring kualitas air produksi PDAM Surya Sembada Surabaya IPAM Ngagel I menggunakan grafik kendali $M E C 1$ dan $M E C 2$, selanjutnya adalah membandingkan kedua grafik kendali tersebut pada setiap musim. Berdasarkan analisis yang sudah dilakukan dapat diketahui bahwa pada perbandingan niai pembobot yang sama di musim kemarau maupun musim penghujan, grafik kendali $M E C 1$ memiliki jumlah pengamatan out of control lebih banyak dari grafik kendali $M E C 2$. Oleh karena itu pada kasus pada data penelitian kualitas air di IPAM Ngagel I grafik kendali $M E C I$ lebih sensitif jika dibandingkan dengan grafik kendali $M E C 2$.

\section{Identifikasi Out of Control}

1. Identifikasi Out of Control Menggunakan Grafik Kendali MEC1

Pada proses identifikasi penyebab out of control menggunakan grafik kendali $M E C 1$ digunakan nilai pembobot $\lambda=0,3$ dan $U C L=18,720$. Kombinasi variabel yang digunakan untuk identifikasi adalah variabel turbidity dengan sisa Chlor pada Gambar 13, variabel turbidity dengan zat organik pada Gambar 14, serta variabel zat organik dengan sisa Chlor seperti pada Gambar 15.

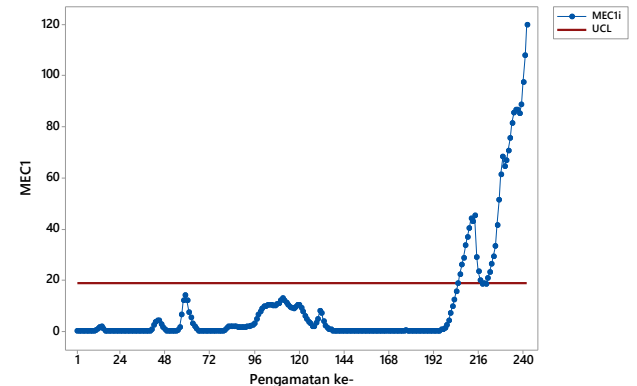

Gambar 13. Identifikasi $O O C$ Menggunakan $M E C l$ Variabel Turbidity dan Zat Organik di Musim Kemarau

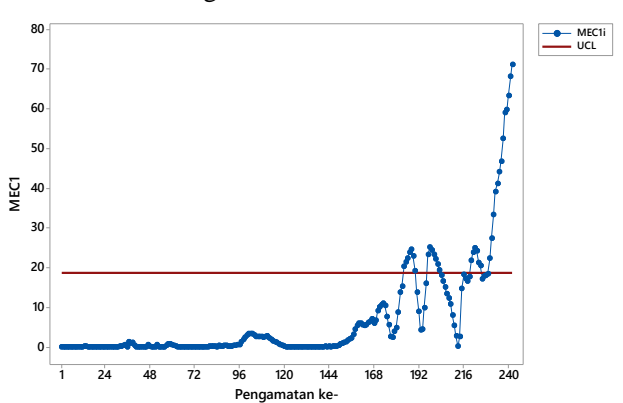

Gambar 14. Identifikasi OOC Menggunakan MEC1 Variabel Turbidity dan Sisa Chlor di Musim Kemarau

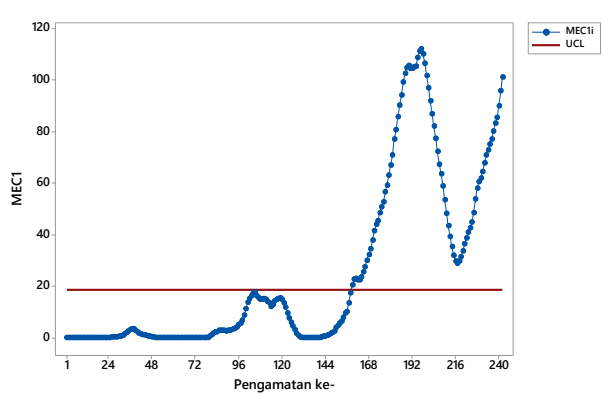

Gambar 15. Identifikasi $O O C$ Menggunakan $M E C 1$ Variabel Zat Organik dan Sisa Chlor di Musim Kemarau

Pada identifikasi out of control dengan tiga kombinasi variabel didapatkan informasi bahwa pada kombinasi variabel turbidity dan zat organik memiliki jumlah pengamatan out of control sebanyak 35 pengamatan. Selanjutnya pada kombinasi variabel turbidity dengan sisa Chlor terdapat 33 pengamatan out control, sedangkan pada kombinasi variabel zat organik dan sisa Chlor terdapat 84 pengamatan out of control. Berdasarkan hasil identifikasi disimpulkan bahwa variabel zat organik merupakan variabel yang berkontribusi bersar penyebab out of control. Selanjutnya adalah proses identifikasi variabel penyebab out of control terbanyak di musim penghujan.

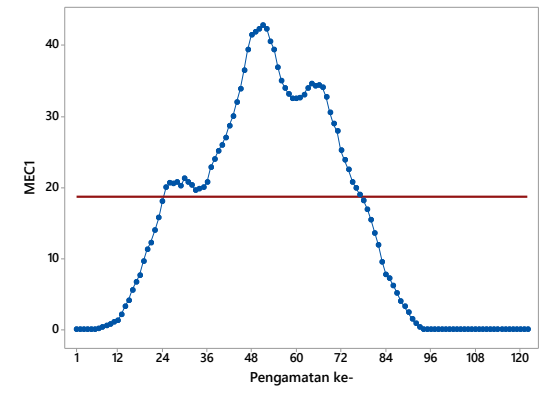

Gambar 16. Identifikasi OOC Menggunakan MEC1 Variabel Turbidity dan Zat Organik di Musim Penghujan 


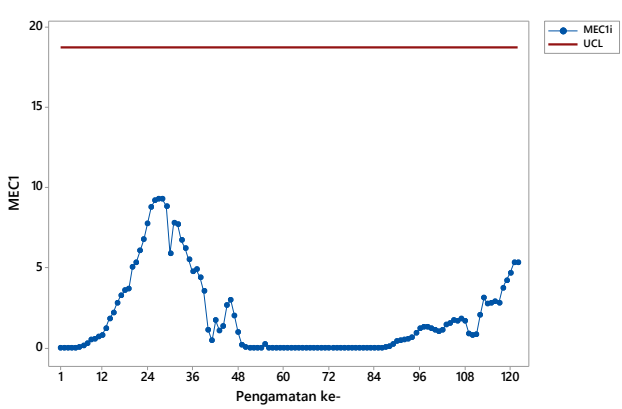

Gambar 17. Identifikasi $O O C$ Menggunakan $M E C 1$ Variabel Turbidity dan Sisa Chlor di Musim Penghujan

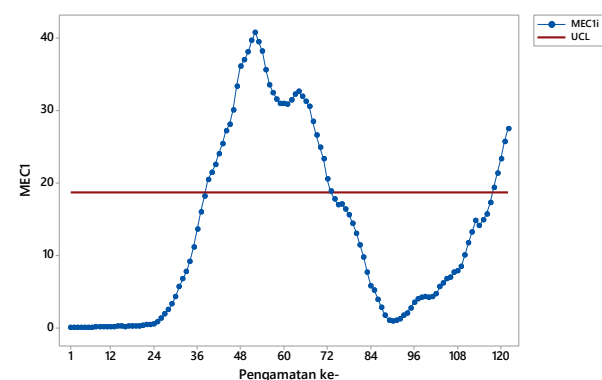

Gambar 18. Identifikasi OOC Menggunakan $M E C l$ Variabel Zat Organik dan Sisa Chlor di Musim Penghujan

Berdasarkan hasil identifikasi out of control kombinasi antara variabel turbidity dengan zat organik pada Gambar 16 terdapat 53 pengamatan out of control. Pada Gambar 17 yaitu hasil identifikasi out of control dengan kombinasi variabel turbidity dan sisa Chlor tidak terdapat pengamatan out of control artinya proses produksi air produksi dengan kombinasi antara variabel turbidity dan sisa Chlor terkendali secara statistik, sedangkan pada kombinasi variabel zat organik dan sisa Chlor terdapat 40 pengamatan out of control sehingga dapat disimpulkan bahwa variabel zat organik merupakan variabel yang berkontribusi besar terhadapa adanya pengamatan out of control di musim penghujan. Setelah dilakukan identifikasi out of control menggunakan grafik kendali MEC2.

2. Identifikasi Out of Control Menggunakan Grafik Kendali $M E C 2$

Seperti yang dilakukan pada identifikasi penyebab out of control menggunakan grafik kendali $M E C 1$, pada identifikasi menggunakan grafik kendali $M E C 2$ juga dilakukan pada musim kemarau dan penghujan namun dengan nilai pembobot 0,1 yaitu sebagai nilai pembobot optimal pada monitoring menggunakan grafik kendali $M E C 2$ sebelumnya dan $U C L=1,81$.

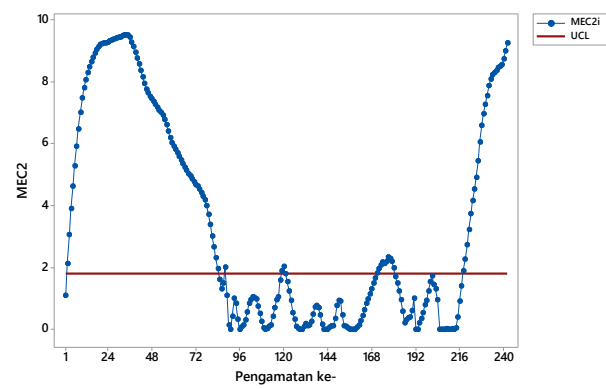

Gambar 19. Identifikasi OOC Menggunakan MEC2 Variabel Turbidity dan Zat Organik di Musim Kemarau

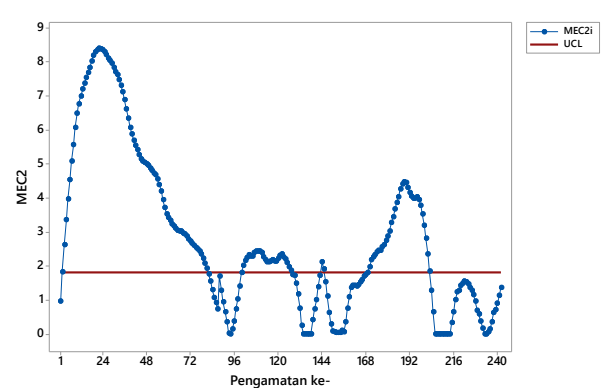

Gambar 20. Identifikasi OOC Menggunakan MEC2 Variabel Turbidity dan Sisa Chlor di Musim Kemarau

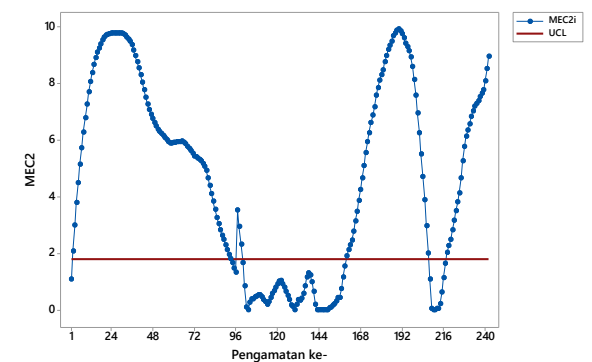

Gambar 21. Identifikasi OOC Menggunakan MEC2 Variabel Zat Organik dan Sisa Chlor di Musim Kemarau

Pada identifikasi penyebab out of control proses produksi air di musim kemarau dengan kombinasi variabel turbidity dan zat organik seperti pada Gambar 19 diketahui bahwa terdapat 120 pengamatan out of control. Kemudian, pada identifikasi dengan kombinasi variabel turbidity dan sisa Chlor pada Gambar 20 hanya terdapat 116 pengamatan out of control, sedangkan pada kombinasi variabel zat organik dan sisa Chlor dengan hasil pada Gambar 21 memiliki jumlah pengamatan out of control terbanyak yaitu 168 pengamatan out of control. Berdasarkan ketiga kombinasi variabel tersebut, kombinasi variabel yang memiliki jumlah out of control cukup banyak adalah kombinasi variabel turbidity dengan zat organik serta variabel zat organik dengan sisa Chlor sehingga dapat disimpulkan bahwa variabel zat organik berpengaruh besar pada out of control.

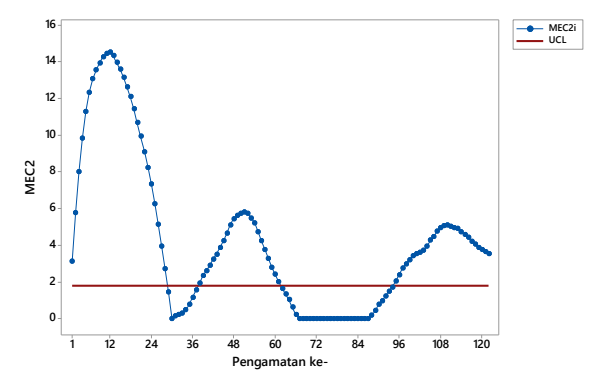

Gambar 22. Identifikasi OOC Menggunakan MEC2 Variabel Turbidity dan Zat Organik di Musim Penghujan

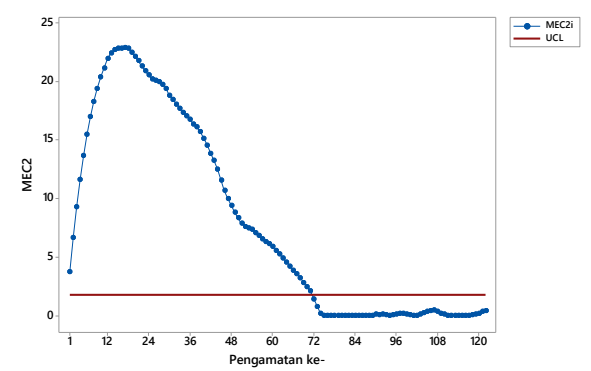

Gambar 23. Identifikasi OOC Menggunakan MEC2 Variabel Turbidity dan Sisa Chlor di Musim Penghujan 


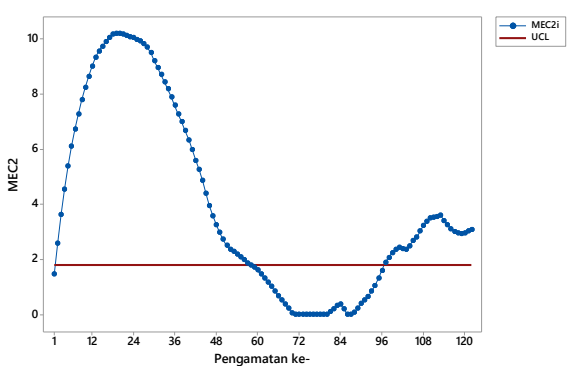

Gambar 24. Identifikasi OOC Menggunakan MEC2 Variabel Zat Organik dan Sisa Chlor di Musim Penghujan

Proses identifikasi penyebab out of control dengan kombinasi variabel turbidity dan zat organik pada Gambar 22 memiliki jumlah pengamatan out of control sebanyak 80 pengamatan. Kombinasi variabel turbidity dan sisa Chlor terdapat 71 pengamatan out of control, sedangkan pada kombinasi variabel zat organik dan sisa Chlor terdapat 73 pengamatan out of control. Berdasarkan tiga kombinasi tersebut, kombinasi variabel turbidity dan zat organik serta variabel zat organik dengan sisa Chlor memiliki jumlah pengamatan out of control lebih banyak, sehingga dapat disimpulkan bahwa pada musim kemarau variabel yang berpengaruh besar pada out of control adalah variabel zat oragnik.

\section{E. Kapabilitas Proses}

Kapabilitas proses pada penelitian ini dilakukan untuk mengukur kemampuan kinerja proses produksi air PDAM Surya Sembada Surabaya IPAM Ngagel I. Suatu proses dikatakan kapabel ketika keseluruhan produk yang dihasilkan berada dalam batas spesifikasi yang telah ditentukan. Berikut merupakan hasil analisis kapabilitas secara univariat maupun multivariat.

Tabel 3. Perhitungan Kapabilitas Proses

\begin{tabular}{lllll}
\hline \multicolumn{5}{c}{ Musim Kemarau } \\
\hline Variabel & $\boldsymbol{P}_{\boldsymbol{p}}$ & $\boldsymbol{P}_{\boldsymbol{p} \boldsymbol{k}}$ & $\boldsymbol{M P}_{\boldsymbol{p}}$ & $\boldsymbol{M P}_{\boldsymbol{p} \boldsymbol{k}}$ \\
\hline Kekeruhan & 3,36 & 1,18 & & \\
Zat Organik & 0,83 & 0,43 & 1,56 & 0,69 \\
Sisa Chlor & 0,50 & 0,47 & & \\
\hline \multicolumn{5}{c}{ Musim Penghujan } \\
\hline Variabel & $\boldsymbol{P}_{\boldsymbol{p}}$ & $\boldsymbol{P}_{\boldsymbol{p} \boldsymbol{k}}$ & $\boldsymbol{M P}_{\boldsymbol{p}}$ & $\boldsymbol{M P}_{\boldsymbol{p k}}$ \\
\hline Kekeruhan & 3,37 & 1,05 & & \\
Zat Organik & 0,70 & 0,25 & 1,54 & 0,51 \\
Sisa Chlor & 0,58 & 0,24 & & \\
\hline \hline
\end{tabular}

Tabel 3 menjelaskan bahwa secara univariat variabel turbidity memiliki tingkat presisi yang baik karena memiliki nilai $P_{p}>1,33$ pada musim kemarau dan penghujan, sedangkan variabel zat organik dan sisa Chlor dapat dikatakan memiliki tingkat presisi yang kurang baik karena memiliki nilai $P_{p}<$ 1,33. Berdasarkan nilai $P_{p k}$ yang kurang dari 1,33 dapat disimpulkan bahwa ketiga karakteristik kualitas memiliki akurasi yang kurang baik. Pada kapabilitas proses secara multivariat didapatkan informasi bahwa pada musim kemarau dan penghujan memiliki nilai $M P_{p}>1,33$ yang artinya proses produksi air di IPAM Ngagel I memiliki presisi baik. Hal tersebut berkebalikan dengan hasil perhitungan $M P_{p k}$ di musim kemarau dan penghujan yang memiliki nilai kurang dari 1,33 yang artinya akurasi pada proses produksi air di IPAM Ngagel I kurang baik. Kesimpulan yang dapat diambil adalah secara multivariat proses produksi air di IPAM Ngagel I telah mencapai tingkat presisi yang diinginkan namun memiliki akurasi yang rendah.

\section{KESIMPULAN DAN SARAN}

Pada monitoring kualitas air di PDAM Surya Sembada Surabaya IPAM Ngagel I menggunakan grafik kendali $M E C 1$ dan $M E C 2$ menunjukkan bahwa proses produksi air tidak terkendali secara statistik di musim kemarau maupun musim hujan. Variabel penyebab out of control terbanyak pada musim hujan dan kemarau adalah variabel zat organik. Pada perbandingan grafik kendali $M E C 1$ dan $M E C 2$ dikatakan bahwa monitoring kualitas pada grafik kendali MEC1 lebih sensitif daripada grafik kendali $M E C 2$, karena memiliki jumlah pengamatan out of control lebih banyak. Berdasarkan nilai $P_{p}$ dan $P_{p k}$ pada analisis kapabilitas proses secara univariat hanya variabel turbidity pada proses produksi air produksi di PDAM Surya Sembada Surabaya IPAM Ngagel I tidak kapabel. Pada analisis kapabilitas proses berdasarkan nilai $M P_{p}$ dan $M P_{p k}$ secara multivariat didapatkan hasil bahwa proses produksi air produksi di PDAM Surya Sembada Surabaya IPAM Ngagel I tidak kapabel.

Saran yang bisa diberikan pada PDAM Surya Sembada Surabaya IPAM Ngagel I adalah dapat mengevaluasi proses produksi air produksi terutama pada proses monitoring variabel zat organik pada air karena variabel zat organik merupakan variabel penyebab out of control terbanyak. Saran untuk peneliti selanjutnya adalah untuk mengetahui metode yang sesuai untuk data karakteristik air produksi di PDAM Surya Sembada Surabaya IPAM Ngagel I karena pada penelitian ini data yang digunakan tidak mengikuti persebaran distribusi normal multivariat.

\section{DAFTAR PUSTAKA}

[1] N. V. Suseno and M. Widyastuti, "Analisis Kualitas Air PDAM Tirta Manggar Kota Balikpapan," Jurnal Bumi Indonesia Vol. 6 No. 1 Tahun 2017, pp. 1-8, 2017.

[2] W. Indarsih, S. Suprayogi and M. Widyastuti, "Kajian Kualitas Air Sungai Bedog Akibat Pembuangan Limbah Cair Sentra Industri Batik Desa Wijirejo," Majalah Geografi Indonesia Vol. 25, No. 1, Maret 2011, pp. 40-54, 2011.

[3] PDAM Surya Sembada Surabaya, "Visi dan Misi PDAM Surya Sembada Surabaya" 2012. [Online]. Available: https://www.pdam-sby.go.id/page.php?get=visi-misi\&bhs $=1$.

[4] J. Heizer, B. Render and C. Munson, Principles of Operation Management, New York: Pearson Education Limited, 2017.

[5] R. A. Johnson and D. Wichern, Applied Multivariate Statistical Aanalysis, United States of America: Prentince Hall, 2007.

[6] D. F. Morrison, Multivariate Statistical Methods, Forth Edition ed. USA: McGraw-Hill, Inc., 2005.

[7] D. C. Montgomery, Introduction to Statistical Quality Control, USA: John Wiley \& Sons, Inc, 2013.

[8] S. Raissi, "Multivariate Process Capability Indices on The Presence of Priority for Quality Characteristics," Journal of Industrial Engineering International, pp. 27-36, 2009.

[9] J. O. Ajadi and M. Riaz, "Mixed Multivariate Ewma-Cusum Control Charts for an Improved Process Monitoring," Сommunications in Statistics - Theory and Mathods, pp. 1-37, 2016. 